\title{
Evaluation of Postharvest Burning and Fungicides to Reduce the Polyetic Rate of Increase of Choke Disease in Orchardgrass Seed Production
}

\author{
W. F. Pfender and S. C. Alderman, USDA-ARS National Forage Seed Production Research Center/Oregon State \\ University Department of Botany and Plant Pathology, 3450 SW Campus Way, Corvallis 97331
}

\begin{abstract}
Pfender, W. F., and Alderman, S. C. 2003. Evaluation of postharvest burning and fungicides to reduce the polyetic rate of increase of choke disease in orchardgrass seed production. Plant Dis. 87:375-379.

Epichloë typhina, causal agent of choke disease, is detrimental to orchardgrass seed production. The fungus grows systemically, persists indefinitely as an endophyte within the perennial host, and produces a stroma bearing conidia and ascospores at the time of host flowering. The ascospores or conidia are thought to infect plants through the cut ends of tillers after swathing at harvest. The objective of this study was to evaluate the potential of systemic fungicides and postharvest treatments (burning and reclipping) to reduce the rate of increase of choke disease among plants. The fungicides propiconazole and azoxystrobin reduced germination of conidia of E. typhina in vitro, but had no effect on development of stroma or viability of conidia produced on infected plants. In field tests, fungicides applied to the cut ends of tillers after harvest were ineffective at reducing the rate of increase in disease. Likewise, reclipping of orchardgrass stubble after harvest, in an attempt to remove incipient infections in the tillers, did not reduce the rate of disease increase in the stand. However, propane-assisted burning of postharvest stubble did reduce the polyetic epidemic rate to $2.7 \%$ per year, compared with approximately $9.2 \%$ per year in plots receiving the fungicide, reclipping, or control treatments. The results suggest that postharvest burning may be useful in controlling choke disease and raise the possibility that there are infection courts other than the pith of cut reproductive tillers.
\end{abstract}

Additional keywords: cultural control, Dactylis glomerata, polyetic disease

Orchardgrass (Dactylis glomerata L.) is a high-quality forage grass species grown on millions of acres throughout the United States and other parts of the world. In North America, the pathogen Epichloë typhina recently became established in orchardgrass seed production fields in the Pacific Northwest $(1,7)$. Choke disease, caused by this fungus, can be a limiting factor for orchardgrass seed production by effectively preventing emergence of the seed head (14). In Europe, where the disease has been present for decades $(5,13)$, choke is uncommon in the first year of seed production in a field, but becomes increasingly prevalent in subsequent years until the crop may have to be abandoned for seed production in the third or fourth year $(9,13)$. The major economic impact of choke, reduced seed yield, is compounded by the increase in stand-establishment costs. Before choke disease was introduced into the seed production region for or-

Corresponding author: W. F. Pfender

E-mail: pfenderw@onid.orst.edu

Accepted for publication 1 November 2002.

Publication no. D-2003-0127-02R

This article is in the public domain and not copyrightable. It may be freely reprinted with customary crediting of the source. The American Phytopathological Society, 2003. chardgrass in the United States, it was common for an orchardgrass seed field to be in production for 8 to 20 years.

E. typhina is an endophyte closely related to fungi in the form-genus Neotyphodium. The fungus grows systemically but asymptomatically as mycelium in the host until the time of flowering, when the fungus rapidly engulfs the floral apex and surrounding leaves, and develops a felt-like stroma on the plant surface $(4,10,11)$. Conidia and/or ascospores formed in the stroma and dispersed to other plants initiate the next annual infection cycle. However, the timing and site(s) of infection of orchardgrass by E. typhina have not been determined conclusively.

Western and Cavett (13), working in Great Britain in the mid-twentieth century, found no evidence for direct infection of intact or wounded vegetative tissue by conidia or ascospores of E. typhina. They were also unable to obtain infection of flowers. In contrast, more recent research with Epichlö spp. on other hosts has demonstrated floral infection that may result in infected seeds (2). However, there has been no demonstration in orchardgrass of seedborne infection by E. typhina resulting in transmission to the next generation $(10,13)$.

The only experimental inoculations of orchardgrass that resulted in choke disease the next season were achieved by application of conidia or ascospores to the cut ends of seed stalks after harvest (13). This infection process is currently accepted as the mode of entry of E. typhina into orchardgrass (9). After a plant is infected, the pathogen can colonize new tillers that develop from the infected tiller(s), although the rate and timing of spread of E. typhina within plants has not been determined. If the typical mode of infection is by the pathogen entering the host stubble after harvest, it may be possible to reduce spread of the disease by interfering with establishment of infection at this site. The stroma of E. typhina dries rapidly after being cut from the plant during harvest, and within hours of cutting loses the ability to eject ascospores if not supplied with water (3). Despite the fact that E. typhina cannot persist outside of host tissue, and is spread among plants during a relatively short period of the year, mid-May to midJune for conidia and June for ascospores, E. typhina can produce a significant polyetic (multi-year) epidemic (15) because orchardgrass is grown as a perennial crop.

An important component of managing polyetic plant diseases is reducing the rate of increase of annual infection cycles. Therefore, one management strategy for choke disease of orchardgrass seed crops would be to eliminate nascent infections in the putative infection court (cut stems) after harvest, when the airborne spore load has essentially disappeared and additional infections are not possible for that year. Also, because the fungus is spread among plants only during the relatively brief period when spores are produced, application of fungicides might be effective by reducing spore production or viability.

The objectives of this research were to test fungicide efficacy in laboratory and field experiments, and to assess the efficacy of reclipping or burning stubble for reducing the annual rate of choke disease increase.

\section{MATERIALS AND METHODS}

Laboratory and greenhouse tests of fungicide efficacy. Systemic fungicides labeled for use on orchardgrass seed crops in the United States were tested in three separate experiments for their ability to inhibit stroma formation or conidia germination by $E$. typhina. Plants of orchardgrass (cv. Takena) infected with $E$. typhina were obtained by collecting individual tillers of plants symptomatic of choke disease from a commercial or- 
chardgrass field and transplanting into pots. The potted diseased plants were grown in a greenhouse at 18 to $22^{\circ} \mathrm{C}$ for 3 months, then stroma formation was stimulated by inducing the plants to flower. Floral induction was achieved by subjecting the plants to days with an 8-h photoperiod for 12 weeks, followed by days with a 16-h photoperiod for 4 weeks, in a greenhouse with 17 to $19^{\circ} \mathrm{C}$ day and 9 to $11^{\circ} \mathrm{C}$ night temperatures.

Plants were sprayed with fungicide or water (control treatment) just before panicle emergence, typically before most stromata were visible. Each stroma was labeled based on the date of emergence, to record whether the particular stroma was exposed to fungicide before or after emergence. The effect of fungicides upon stroma formation was tested in a completely randomized design (CRD) experiment with eight replications per treatment. The experimental unit was a single pot containing one plant. The experiment was done three times. In one experiment (trial 1 ), plants were sprayed a second time 2 weeks after the first spray. In trials 2 and 3 , plants were sprayed only once. The fungicide treatment was a mix of propiconazole (Tilt 3.6 EC) and azoxystrobin (Quadris $2.08 \mathrm{SC}$ ) applied at a rate equivalent to 440 and $660 \mathrm{ml}$ of product per ha $(184 \mathrm{~g}$ and $150 \mathrm{~g}$ active ingredient [a.i.]), respectively, in 187 liters of water per ha with $1 \%$ surfactant (polyol fatty acid esters and derivatives, $2.8 \mathrm{~kg}$ a.i./ha) (Agridex, Helena, MT). The fungicides were manufactured by Syngenta, Inc. (Basel, Switzerland). Fungicides were applied to plants using a motorized track sprayer in a spray booth. Plants were observed for 50 days after spraying, the stromata produced per plant during this period were counted, and the length of each stroma was measured. The experiment was done three times.

To determine if fungicide sprays to the stroma reduced viability of conidia subsequently released from the stroma, conidia were collected from stromata from fungicide-treated and control plants 4 days after treatment and tested for germination. A no. 9 camel hair brush was used to collect conidia from one stroma on each of four fungicide-treated and four control plants of the experiment described above. Conidia from each stroma were transferred to 10 to $20 \mathrm{ml}$ of water, and approximately $5 \mu \mathrm{l}$ of the conidial suspension was transferred to a glass microscope slide, one slide per stroma. Slides were placed in separate petri dishes containing moist tissue paper to maintain high humidity, covered, and incubated at $20^{\circ} \mathrm{C}$. After $24 \mathrm{~h}$, a drop of aniline blue stain $(30 \mathrm{mg}$ aniline blue, $20 \mathrm{ml}$ water, $10 \mathrm{ml}$ glycerol, and $10 \mathrm{ml}$ lactic acid) was placed on each slide and the conidia were examined at $\times 200$ for germination. Percent germination was calculated based on the first 100 conidia observed on each slide. The experiment was done two times.

The direct effect of fungicide exposure to conidia during germination was tested also. Nonsprayed stromata from the experiment described above were used as the conidia source. Three of the stromata were cut into 0.5 - to $1.0-\mathrm{cm}$-long sections, and three of these small stroma sections were selected at random for each experimental unit. There were four treatments: propiconazole, azoxystrobin, propiconazole plus azoxystrobin, and control. There were four replicates per treatment in a CRD. For each replicate, the three stroma sections were agitated by hand for about $10 \mathrm{~s}$ in a $0.5-\mathrm{ml}$ fungicide suspension or water. The highest concentration of each fungicide was equivalent to that prepared for typical spraying in commercial orchardgrass seed crops, i.e., $960 \mathrm{mg}$ a.i./liter for propiconazole and $800 \mathrm{mg}$ a.i./liter for azoxystrobin. The fungicides were also tested for effect on conidia germination at 10 -fold dilutions from these maximum concentrations to 0.096 and $0.080 \mathrm{mg} / \mathrm{liter}$, respectively. For each replicate, one 5- $\mu$ d drop of the conidia suspension in fungicide solution or water was transferred to a glass microscope slide, and germination was assessed as described previously after $24 \mathrm{~h}$. The experiment was repeated, and data from both trials were pooled for analysis because ANOVA showed no significant $(P=0.05)$ effect of trial.

Field study of stubble treatments. Seed of the orchardgrass cultivar Takena was planted in a $25 \times 15 \mathrm{~m}$ area at a row spacing of $30 \mathrm{~cm}$ on 15 September 1997 at the Hyslop Experiment Farm of Oregon State University near Corvallis. Fertilizer (67 kg N/ha as urea) was applied in March (1998, 1999, 2000, 2001), and again in November (1998, 1999, 2000). Propamide herbicide (Kerb; Rohm and Haas, Philadelphia, PA) was applied each December starting in 1998 to control volunteer orchardgrass. At the end of June in 1998, 1999, and 2000, the seed crop was cut at a height of approximately $10 \mathrm{~cm}$ with a swather and left to dry in a windrow. The windrow was removed several days after cutting, immediately before the first treatments were applied. Individual plots, seven rows wide by $3 \mathrm{~m}$ long with a $0.6-\mathrm{m}$ border, were demarcated after harvest in 1998.

To provide an inoculum source for disease development, 5 to 10 actively sporulating mature stromata of E. typhina were placed in the center of each plot for several days immediately after harvest in 1998, 1999, and 2000 (Table 1). In 1998, stromata comprising the inoculum source were borne on infected plants that had been dug from a naturally infected orchardgrass field and placed in 22-cm-diameter pots, one plant per pot. In 1999 and 2000, orchardgrass stems bearing mature stromata were cut from a naturally infected crop and the cut ends immersed immediately in water. The stems were placed into the experimental plots in vessels of water. In 1998 and 1999, overhead irrigation was applied to the plots on each of two evenings, and in 2000 there were several days with short periods of light rain during the time that stromata of E. typhina were present in the plots (Table 1). No additional rainfall occurred in July in any of the 3 years.

Effect of postharvest treatments was evaluated in a randomized complete block experimental design with seven treatments and five replications. Treatments applied to the 10-cm-tall stubble were: early burn, late burn, early reclip, late reclip, early fungicide, late fungicide, nontreated control. Treatment dates for early treatments were 3 July 1998 and 6 July 1999 (Table

Table 1. Postharvest treatments of orchardgrass ${ }^{\mathrm{w}}$ in choke disease trials

\begin{tabular}{|c|c|c|c|c|c|c|c|}
\hline \multirow[b]{2}{*}{ Year } & \multirow[b]{2}{*}{ Harvest date } & \multirow[b]{2}{*}{ Stubble height } & \multicolumn{2}{|c|}{ Introduced inoculum } & \multirow{2}{*}{$\begin{array}{c}\text { Sprinkler irrigation } \\
\text { or rain }\end{array}$} & \multicolumn{2}{|c|}{ Treatment ${ }^{\mathrm{y}}$ dates } \\
\hline & & & Source $^{\mathrm{x}}$ & Dates & & Early & Late \\
\hline 1998 & Jun 30 & $10 \mathrm{~cm}$ & Potted plants & Jun 30 - Jul 2 & $\begin{array}{l}\text { Jun 30: } 15 \mathrm{~mm} \\
\text { Jul 1: } 10 \mathrm{~mm}\end{array}$ & Jul 3 & Jul 16 \\
\hline 1999 & Jun 30 & $10 \mathrm{~cm}$ & $\begin{array}{l}\text { Cut stems } \\
\text { in water }\end{array}$ & Jul 2 - Jul 3 & $\begin{array}{l}\text { Jul 1: } 15 \mathrm{~mm} \\
\text { Jul 2: } 10 \mathrm{~mm}\end{array}$ & Jul 6 & Jul 20 \\
\hline 2000 & Jun 30 & $10 \mathrm{~cm}$ & $\begin{array}{l}\text { Cut stems } \\
\text { in water }\end{array}$ & Jun 30 - Jul 5 & $\begin{array}{l}\text { Jun 30: } 2 \mathrm{~mm} \\
\text { Jul 3: } 5 \mathrm{~mm} \\
\text { Jul 4: } 6 \mathrm{~mm}\end{array}$ & $-{ }^{\mathrm{z}}$ & Jul 21 \\
\hline
\end{tabular}

w Orchardgrass cultivar Takena was planted in September 1997. The postharvest stubble was left untreated (control), sprayed with a mixture of propiconazole and azoxystrobin (fungicide treatment), reclipped to a height of $4 \mathrm{~cm}$ (reclip treatment), or burned with a propane torch (burn treatment).

${ }^{x}$ Mature, ascospore-bearing stromata (5 to 10 stromata per plot) on orchardgrass stems collected from a naturally infected orchardgrass crop, either as whole potted plants or as cut stems placed in vessels of water.

y Treatments were applied to postharvest stubble in each plot once per year (either early or late).

${ }^{\mathrm{z}}$ No early treatments were applied in 2000 . 
1 ), and for late treatments were 16 July 1998, 20 July 1999, and 21 July 2000. Treatments were assigned randomly to the plots in 1998 and maintained in the same plots throughout the study. The early treatments were not included in 2000, because there was no statistical difference in the results between early and late treatments applied in 1999. The burn treatments were accomplished with a hand-held propane torch (Handiboy handburner; Manchester Tank Co., Brentwood, TN). Sufficient flaming was applied to burn most of the dead straw and to kill green leaves back to approximately $2 \mathrm{~cm}$ above the ground. Reclipping was done with a sicklebar mower (model 716; BCS America Inc., Matthews, NC) to a height of approximately $4 \mathrm{~cm}$ above the ground. Fungicide applications were made with a backpack sprayer using compressed carbon dioxide (R\&D Sprayers, Baton Rouge, LA) at a pressure of $1.45 \mathrm{~kg} / \mathrm{cm}^{2}$. The application was a tank mix of propiconazole (Tilt 3.6 EC) at $184 \mathrm{~g}$ a.i./ha, azoxystrobin (Quadris $2.08 \mathrm{SC}$ ) at $150 \mathrm{~g}$ a.i./ha, and surfactant (polyol fatty acid esters and derivatives, $2.8 \mathrm{~kg}$ a.i./ha) in 280 liters of water per ha.

The number of tillers exhibiting $E$. $t y$ phina stromata per square meter in each plot was estimated by sampling on 13 June in 1999, 2000, and 2001. Five samples were examined in each plot, each sample consisting of all the tillers within a $0.25-\mathrm{m}^{2}$ area defined by placing a rectangular sampling grid $(0.25 \times 1.0 \mathrm{~m})$ randomly within the plots as described previously (7). The number of E. typhina stromata was counted in each $0.25-\mathrm{m}^{2}$ sample, and the five measurements were averaged to produce a single estimate of diseased tillers per $\mathrm{m}^{2}$ for the replicate plot for statistical analysis. In one sample per plot, the number of healthy reproductive tillers per $0.25 \mathrm{~m}^{2}$ was counted for use in calculating the percent tillers with symptoms of choke disease (number of diseased tillers divided by total number of tillers).

Data analysis. Data from laboratory and greenhouse experiments on fungicide efficacy were analyzed by one-way analysis of variance (ANOVA) with the use of SigmaStat software (SPSS Inc., Chicago, IL). For percent conidia germination, data were transformed before analysis to arcsine square root, to stabilize the variance of data expressed as percentages (12).

Field plot data were analyzed for increase in incidence of choke from 1999 to 2000 and from 2000 to 2001. Levels of choke measured in June 2000 represented the increase in incidence from 1999 to 2000, as virtually no choke was observed in 1999. When the experiment was repeated in 2001, statistical analyses were done on the increase in disease incidence between 2000 and 2001 for each replicate plot (incidence for 2001 minus incidence for 2000). The data for June 2000 were analyzed by ANOVA, and treatment means were compared by Tukey's test (8), using SigmaStat. Results of the 2000 data showed that choke levels in the nonburn treatments (control, reclip, and fungicide treatments) were not statistically different $(P<0.05)$. Therefore, analysis of the data for 2000 to 2001, that is the change in amount of choke between 2000 and 2001 in each plot, was conducted as a $t$ test of burn treatment versus the average of all nonburn treatments. Due to unequal variances between treatments, Welches $t$ test (8) was used for this analysis. In addition to the analysis of change in incidence of disease for each cropping year (1999 to 2000 and 2000 to 2001), treatments were compared for differences in the average rate of disease increase across all years of the study (1999 to 2001). For this analysis, the rate of increase in incidence of choke for each individual replicate plot was estimated for 1999 to 2001, using the line of best fit (calculated by SigmaPlot) from 1999 to 2001. The slope of this line for each plot was then used to compare treatments (five replicate slopes per treatment) by ANOVA, and means were compared using Tukey's test on SigmaStat.

\section{RESULTS}

Laboratory and greenhouse tests of fungicide efficacy. The average time be- tween fungicide treatment and stromata emergence was 22.3 days, standard deviation $=13.6$. In each of the three trials testing the effect of fungicides on stromata production, the ANOVA results showed no significant $(P<0.05)$ difference in number of stromata between plants treated with water (control treatment) and those treated with propiconazole and azoxystrobin (Table 2). Neither the number of stromata per plant nor the size of stromata was reduced by the fungicide applications.

For the two trials in the experiment testing germination of conidia produced subsequent to fungicide treatment of stromata, ANOVA results differed (Table 2). In trial 2 , conidia produced on stromata that had been treated with fungicides 4 days previously showed no significant $(P<0.05)$ reduction in viability as measured by germination in water. In trial 3 , the average reduction in germination due to fungicide treatment was slightly greater than in trial 2 , and statistically significant.

In the experiment testing the direct effect of fungicide exposure on conidia during germination, there was a significant difference $(P<0.05)$ in the percent germination of conidia suspended in water (control) or fungicide solutions (Table 3). The highest concentration of fungicide evaluated, equivalent to that used in commercial fields, reduced germination of conidia significantly regardless of whether the fungicides (propiconazole and azoxystrobin) were used alone or in combination. Propiconazole was the less effective of the two fungicides, with a greater loss of efficacy at lower concentrations than for azoxystrobin. Almost all conidia exposed to the mixture of the two fungicides at full or $1: 10$ concentration failed to germinate, and germination of conidia at 10-fold dilutions from $1: 100$ to $1: 10,000$ was 8,20 , and $40 \%$, respectively, all of which were significantly less than germination of conidia in the nontreated control (94\%).

Field study of stubble treatments. In the field experiments, there was almost no choke disease visible on plants in June 1999, despite inoculation of the plots in

Table 2. Production of stromata and germination of conidia of Epichloë typhina on orchardgrass plants ${ }^{\mathrm{w}}$ treated with fungicide $^{\mathrm{x}}$

\begin{tabular}{|c|c|c|c|c|c|c|c|c|}
\hline \multirow[b]{2}{*}{ Treatment } & \multicolumn{2}{|c|}{$\begin{array}{c}\text { Trial 1 } \\
\text { Spray dates Feb 26 \& Mar } 9 \\
\end{array}$} & \multicolumn{3}{|c|}{$\begin{array}{c}\text { Trial } 2 \\
\text { Spray date Mar } 9 \\
\end{array}$} & \multicolumn{3}{|c|}{$\begin{array}{c}\text { Trial } 3 \\
\text { Spray date Mar } 27 \\
\end{array}$} \\
\hline & $\begin{array}{l}\text { Stromata/ } \\
\text { plant }\end{array}$ & $\begin{array}{c}\text { Stroma } \\
\text { length }(\mathrm{cm})\end{array}$ & $\begin{array}{l}\text { Stromata/ } \\
\text { plant }\end{array}$ & $\begin{array}{c}\text { Stroma } \\
\text { length }(\mathrm{cm})\end{array}$ & $\begin{array}{c}\text { Conidia } \\
\text { germination }\end{array}$ & $\begin{array}{l}\text { Stromata/ } \\
\text { plant }\end{array}$ & $\begin{array}{c}\text { Stroma } \\
\text { length }(\mathrm{cm})\end{array}$ & $\begin{array}{c}\text { Conidia } \\
\text { germination }\end{array}$ \\
\hline Fungicide & 8.4 & 5.9 & 14.0 & 7.7 & $66 \%$ & 10.0 & 9.9 & $55 \%$ \\
\hline Control & 11.4 & 6.8 & 14.8 & 7.3 & $80 \%$ & 10.8 & 8.5 & $81 \%$ \\
\hline$P$ value $^{\mathrm{z}}$ & $\mathrm{ns}$ & $\mathrm{ns}$ & ns & $\mathrm{ns}$ & ns & $\mathrm{ns}$ & $\mathrm{ns}$ & 0.04 \\
\hline
\end{tabular}

${ }^{\mathrm{w}}$ Orchardgrass plants, obtained by vegetative propagation of infected plants collected in a seed crop field, were induced to flower by exposing them to 8 -h daily photoperiod for 12 weeks, then 16-h daily photoperiod for 4 weeks. Plants were grown in pots in a greenhouse, with 1 plant/pot and 8 replicate pots/treatment. Measurements of stroma number and size are for stromata that emerged after fungicide treatment of plants. The number of stromata emerged before fungicide treatment did not differ between the check and fungicide treatments within each trial, and was: 0.3 per plant for trial $1,0.5$ per plant for trial 2, 2.1 per plant for trial 3. Final data were recorded on 15 April.

${ }^{x}$ Fungicide treatment was a mixture of propiconazole and azoxystrobin at 184 and $150 \mathrm{~g} / \mathrm{ha}$, respectively, in 187 liters water/ha.

${ }^{y}$ Germination in water of conidia collected from stromata 4 days after fungicide treatment of stromata (based on 100 conidia from each of 4 replicate plants from the fungicide treatment and control treatment).

z Treatments were not significantly different at $P=0.05$ (ns), or different at the indicated $P$ level. 
July 1998. Two choked stems were observed, one in the "early reclip" treatment and one in a border area of a plot. However, in June 2000 a substantial increase in incidence of choke was evident (Fig. 1). Control plots with no stubble treatment had 38 symptomatic tillers per $\mathrm{m}^{2}$ (Table 4). The mean number of reproductive tillers per $\mathrm{m}^{2}$ (diseased + healthy) was 360 (data not shown), so the incidence of symptomatic plants in the control plots was approximately $11 \%$. In the ANOVA for 2000 data, there was a significant $(P<0.05)$ effect of treatment of the stubble on the number of tillers with choke disease. Inci- dence of choke in 2000 in plots where stubble was treated either with fungicides or by reclipping in July 1998 and 1999 was not significantly different from that in nontreated plots. Where stubble was burned with a propane torch, the incidence of choke in 2000 was significantly $(P<$ 0.05 ) lower than in the nontreated control plots and in plots receiving other treatments. There was no significant effect of timing of treatments (early or late) on disease incidence; fungicide or reclipping treatments were ineffective at reducing incidence of choke whether applied within a week of harvest (early) or 2 to 3 weeks

Table 3. Germination of conidia of Epichloë typhina in the presence of fungicides ${ }^{\mathrm{x}}$

\begin{tabular}{lcc}
\hline Fungicide $^{\mathbf{y}}$ & Concentration $(\mathbf{m g} / \mathbf{l i t e r})$ & ${\text { Germination }(\%)^{\mathbf{z}}}^{\text {Control }}$ \\
Propiconazole & 0.096 & $94 \mathrm{a}$ \\
Propiconazole & 0.96 & $94 \mathrm{a}$ \\
Propiconazole & 9.6 & $95 \mathrm{a}$ \\
Propiconazole & 96 & $88 \mathrm{ab}$ \\
Propiconazole & 960 & $54 \mathrm{c}$ \\
Azoxystrobin & 0.08 & $2 \mathrm{~g}$ \\
Azoxystrobin & 0.8 & $76 \mathrm{~b}$ \\
Azoxystrobin & 8.0 & $35 \mathrm{~d}$ \\
Azoxystrobin & 80 & $30 \mathrm{de}$ \\
Azoxystrobin & 800 & $22 \mathrm{e}$ \\
Propiconazole + azoxystrobin & $0.096+0.08$ & $1 \mathrm{~g}$ \\
Propiconazole + azoxystrobin & $0.96+0.8$ & $40 \mathrm{~cd}$ \\
Propiconazole + azoxystrobin & $9.6+8.0$ & $20 \mathrm{e}$ \\
Propiconazole + azoxystrobin & $96+80$ & $8 \mathrm{f}$ \\
Propiconazole + azoxystrobin & $960+800$ & $1 \mathrm{~g}$ \\
\hline
\end{tabular}

${ }^{x}$ Conidia were collected from stromata of E. typhina on orchardgrass plants, then suspended in water (control treatment) or a solution of fungicide on a glass microscope slide. After incubating $24 \mathrm{~h}$ under moist conditions, spores were examined microscopically, and percent spores germinated was determined.

y Fungicides, manufactured by Syngenta (Basel, Switzerland), were propiconazole (Tilt) and azoxystrobin (Quadris). Concentrations are for active ingredient.

${ }^{\mathrm{z}}$ Mean percent germination is average of two trials, with four replicates per treatment in each trial. Arcsine square root transformation was used before analysis to stabilize variance. Values followed by the same letter do not differ statistically $(P=0.05)$ based on Tukey's test $(12)$.

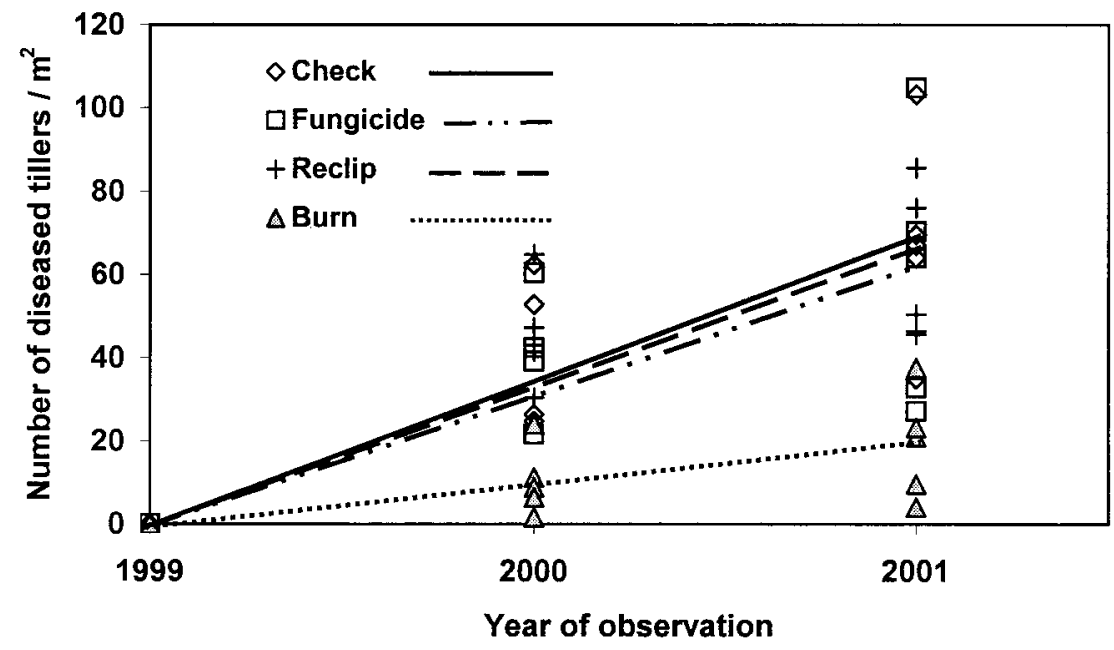

Fig. 1. Number of diseased tillers (exhibiting stromata of Epichloë typhina) per $\mathrm{m}^{2}$ in plots of an orchardgrass seed crop to which postharvest treatments were applied the previous year $(1998,1999$, and 2000). The 10-cm-tall postharvest stubble was left untreated (control), sprayed with a mixture of propiconazole and azoxystrobin (fungicide treatment), reclipped to a height of $4 \mathrm{~cm}$ (reclip treatment), or burned with a propane torch (burn treatment) approximately 2.5 weeks after harvest. Each point represents one replicate plot, and there are five replicates per treatment. Each line is the mean of five slopes per treatment (one per replicate plot), representing the increase in incidence of choke disease from 1999 to 2001.

after harvest (late), and there was no significant difference in incidence of choke between early and late burning of plots (Table 4). Early treatments were not applied in July 2000, as the incidence of choke did not differ from late treatments applied the previous year.

The ANOVA for measurements taken in 2001 indicated a significant $(P<0.05)$ effect of treatment on change in number of symptomatic tillers per plot between 2000 and 2001. The increase in incidence of choke from 2000 to 2001 was significantly lower in plots in which the stubble was burned than in plots receiving the other treatments (fungicides, reclip, or control) (Table 4). There was no significant difference in incidence of choke among the control, fungicide, and reclip treatments. Statistical analysis of the slopes for average increase in number of symptomatic tillers per plot from 1999 to 2001 showed the rate of increase to be significantly lower for the burn treatment (9.6 tillers exhibiting $E$. typhina stromata per $\mathrm{m}^{2}$ per year) than for the nonburn treatments (31 to 35 tillers exhibiting E. typhina stromata per $\mathrm{m}^{2}$ per year) (Table 4 and Fig. 1). These results equated to an increase of 2.7 and $9.2 \%$ symptomatic tillers per year for the burn and nonburn treatments, respectively.

\section{DISCUSSION}

E. typhina infects orchardgrass by gaining access to the meristematic tissue, where it colonizes and ultimately destroys the floral apex the following season $(4,10,14)$. Although E. typhina can infect seed of some hosts (14), seed infection has not been demonstrated for E. typhina in orchardgrass. Regardless of the seedborne nature of this fungus in orchardgrass, seed infection would not be a significant factor in these field experiments because volunteer seedlings were eliminated from the stand using herbicide treatments. Therefore, the polyetic increase in incidence of choke was probably due to successful infection of meristematic tissues by spores of the fungus each year. It is possible that this infection resulted from spores deposited on the cut ends of reproductive tillers after harvest, as suggested by Western and $\mathrm{Ca}$ vett (13), with subsequent growth of the fungus systemically in infected tillers. The rate of increase in choke in field plots in this study was similar to that reported in Europe, where increases of $10 \%$ per year are common after the first year of seed production, which is typically disease-free $(5,9)$.

Systemic fungicides currently available for use on orchardgrass seed crops in the United States did not appear to be effective in preventing infection or subsequent development of E. typhina on plants. Stroma formation by the endophytic fungus apparently was not affected by applications of propiconazole and azoxystrobin before stroma emergence, despite the toxicity of 
these materials to the fungus as measured by inhibition of spore germination in vitro. Even when fungicides were sprayed directly onto emerged stromata at a commercial rate of application, production of viable spores continued. The slight reduction in viability of these conidia was not of number of spores potentially released by individual stroma. Application of fungicides to the putative infection court (cut tillers) did not slow disease development, even when the applications were made within several days of the presumed period of natural infection. The lack of fungicide efficacy may be due to insufficient concentration of fungicide at the infection sites. In addition, it is possible that previous conclusions about the timing of infection (13) are incorrect.

Based on the infection process of orchardgrass by E. typhina as described by Western and Cavett (13), it might be possible to disrupt the infection process by reclipping orchardgrass stubble after harvest to remove the slow-growing mycelium (1.0 to $1.8 \mathrm{~mm} /$ day in the tiller pith [13]) before it can reach the crown of the plant. This management option was suggested by Fermaud (3). However, the field experiments described in this study demonstrated that reclipping was completely ineffective at reducing the rate of disease increase. by reclipping could become infected, this was unlikely in the experiments because sporulating stromata were removed from the field at least 2 weeks before the second (late) reclip treatment was done. Most orchardgrass crops in the region, and all orchardgrass stands within several kilometers of the test site, had been swathed at least 2 weeks before the reclip treatment, removing other possible sources of inocupractical significance, given the large Although it is possible the wounds caused

lum. These results suggest there may be additional infection courts for E. typhina besides the cut ends of tillers in the stubble.

Burning destroys stubble and some of the lower leaves, but does not damage the crown and meristems. Burning effectively reduced the polyetic infection rate in this study. This suggests the pathogen may reside in tissues near the crown, from which it later infects meristematic tissue. The fact that infection rate was not eliminated but reduced (3\% per year, compared to $9 \%$ per year for the control) suggests that, within a few days to 2.5 weeks after harvest, some infections are established in the crown or lower part of the plant not reached by subsequent flaming.

The endophyte Neotyphodium spp. (formerly Acremonium spp.), which is closely related to Epichlö̈ spp., was observed to grow epiphyllously on species of Bromus, Festuca, and Poa (6). Although there are no reports of epiphyllous growth of Epichloë spp. in orchardgrass, it is possible that such growth occurs and is involved in the colonization and infection process leading to choke disease. Further investigation is needed to determine the time and site(s) of infection of orchardgrass by E. typhina and the rate of movement of this pathogen within the host plant. Such information could determine, for example, whether a longer delay between cutting and burning might negate the benefit of burning.

The reduction in disease development due to burning has practical significance. Reducing the annual rate of disease increase from 9 to $3 \%$ would prolong the economic life of an orchardgrass stand for seed production, thereby limiting the recurrence of stand establishment costs. Openfield burning of postharvest straw and stubble was once the most common

Table 4. Yearly increases in incidence of choke disease in orchardgrass, and overall mean rate of increase in incidence, for postharvest stubble treated by burning, reclipping, or fungicide application

\begin{tabular}{|c|c|c|c|c|}
\hline \multirow[b]{3}{*}{ Stubble treatment ${ }^{w}$} & \multirow[b]{3}{*}{$\operatorname{Timing}^{\mathrm{x}}$} & \multicolumn{3}{|c|}{ Increase in incidence of symptomatic tillers $/ \mathrm{m}^{2} /$ year } \\
\hline & & \multicolumn{2}{|c|}{$\begin{array}{l}\text { Annual increase } \\
\text { in incidence }\end{array}$} & \multirow{2}{*}{$\begin{array}{c}\text { Mean annual increase } \\
\text { in incidence }\end{array}$} \\
\hline & & 1999-2000 & 2000-2001 & \\
\hline Nontreated control & & $38.4 \mathrm{a}^{\mathrm{z}}$ & 30.0 & $34.8 \mathrm{a}$ \\
\hline \multirow[t]{2}{*}{ Fungicide } & Early & $49.2 \mathrm{a}$ & & \\
\hline & Late & $37.4 \mathrm{a}$ & 22.8 & $31.2 \mathrm{a}$ \\
\hline \multirow{2}{*}{ Reclipped } & Early & $37.3 \mathrm{a}$ & & \\
\hline & Late & $45.3 \mathrm{a}$ & 22.4 & $33.2 \mathrm{a}$ \\
\hline \multirow[t]{2}{*}{ Burned with propane } & Early & $7.0 \mathrm{~b}$ & & \\
\hline & Late & $10.4 \mathrm{~b}$ & $8.8^{*}$ & $9.6 \mathrm{~b}$ \\
\hline$P$ value & & 0.014 & 0.029 & 0.004 \\
\hline
\end{tabular}

${ }^{\mathrm{w}}$ Treatments were applied to postharvest stubble in each plot once per year (either early or late). The 10-cm-tall postharvest stubble was left untreated (control), sprayed with a mixture of propiconazole and azoxystrobin (fungicide treatment), reclipped to a height of $4 \mathrm{~cm}$ (reclip treatment), or burned with a propane torch (burn treatment).

${ }^{\mathrm{x}}$ Early treatments were applied within 1 week after harvest; late treatments were applied 2 to 3 weeks after harvest (see Table 1 for dates).

${ }^{y}$ Rate of increase in incidence of tillers exhibiting choke disease for each treatment calculated from the mean rate of increase in five replicate plots per treatment.

${ }^{\mathrm{z}}$ Means within a column followed by the same letter do not differ significantly $(P=0.05)$ based on Tukey's test $(12)$, and * indicates significant difference $(P=0.05)$ of burn versus the mean of all nonburn treatments based on Welch's $t$ test (8). method of straw removal in the Willamette Valley (where most of the orchardgrass seed is grown in the United States), but the practice is now restricted. Propane-assisted burning of stubble after removal of straw by baling has been used in commercial grass seed production as an alternative to openfield burning. The practice has not been widely adopted, but its use may be reevaluated in light of the possible benefits with respect to managing choke disease. Alternative approaches such as chemical burning with a desiccant, or biological control in the stubble, should be investigated.

\section{ACKNOWLEDGMENTS} tance.

We thank Sheila Seguin for technical assis-

\section{LITERATURE CITED}

1. Alderman, S. C., Pfender, W. F., Welty, R. E., Mellbye, M. E., Cook, R. L., Spatafora, J. W., and Putnam, M. 1997. First report of choke, caused by Epichloë typhina, on orchardgrass in Oregon. Plant Dis. 81:1335.

2. Chung, K. R., and Schardl, C. L. 1997. Sexual cycle and horizontal transmission of the grass symbiont, Epichloë typhina. Mycol. Res. 101:295-301.

3. Fermaud, M. 1986. Epidémiologie de la quenouille du dactyle porte-graine due a Epichloë typhina (Pers. Ex Fr.) Tulasne. Ph.D. thesis. Ecole Nationale Supérieure Agronomique de Montpelier.

4. Kirby, E. J. M. 1961. Host-parasite relations in the choke disease of grasses. Trans. Br. Mycol. Soc. 44:493-503.

5. Large, E. C. 1954. Surveys for choke (Epichloë typhina) in cocksfoot seed crops 1951-1953. Plant Pathol. 3:6-11.

6. Moy, M., Belanger, F., Duncan, R., Freehoff, A., Leary, C., Meyer, W., Sullivan, R., and White, J.F., Jr. 2000. Identification of epiphyllous mycelial nets on leaves of grasses infected by Calvicipitaceous endophytes. Symbiosis 28:291-302.

7. Pfender, W. F., and Alderman, S. C. 1999 Geographical distribution and incidence of orchardgrass choke, caused by Epichloë typhina, in Oregon. Plant Dis. 83:754-758.

8. Ramsey, F. L., and Schafer, D. W. 2002. The Statistical Sleuth: A Course in Methods of Data Analysis. 2nd ed. Duxbury, Pacific Grove, CA.

9. Raynal, G. E. 1991. Libération des ascospores d'Epichloë typhina, agent de la quenouille du dactyle: Consequences pour l'épidémiologie et la lutte. Fourrages 127:345-358.

10. Sampson, K. 1933. The systemic infection of grasses by Epichloë typhina (Pers.) Tul. Trans. Br. Mycol. Soc. 18:30-47.

11. Schardl, C. L. 1996. Epichloë species: Fungal symbionts of grasses. Annu. Rev. Phytopathol. 34:109-130.

12. Steel, R. G. D., and Torrie, J. H. 1960. Principals and Procedures of Statistics. McGrawHill, New York.

13. Western, J. H., and Cavett, J. J. 1959. The choke disease of cocksfoot (Dactylis glomerata) caused by Epichloë typhina (Fr.) Tul. Trans. Br. Mycol. Soc. 42:298-307.

14. White, J. F., Jr., Morrow, A. C., MorganJones, G., and Chambers, D. A. 1991. Endophyte-host associations in forage grasses. XIV. Primary stromata formation and seed transmission in Epichloë typhina: Developmental and regulatory aspects. Mycologia 83:72-81.

15. Zadoks, J. C., and Schein, R. D. 1979. Epidemiology and Plant Disease Management. Oxford University Press, New York. 